\title{
Bulked segregant analysis of the pirarucu (Arapaima gigas) genome for identification of sex-specific molecular markers
}

\author{
I.G. Almeida ${ }^{1}$, P. Ianella ${ }^{2}$, M.T. Faria ${ }^{3}$, S.R. Paiva ${ }^{4}$ and A.R. Caetano ${ }^{4}$ \\ ${ }^{1}$ Programa de Pós-Graduação em Ciências Animais, Universidade de Brasília, \\ Brasília, DF, Brasil \\ ${ }^{2}$ Embrapa Sede, Departamento de Pesquisa e Desenvolvimento, \\ Brasília, DF, Brasil \\ ${ }^{3}$ Embrapa Amazônia Oriental, Belém, PA, Brasil \\ ${ }^{4}$ Embrapa Recursos Genéticos e Biotecnologia, Parque Estação Biológica, \\ Brasília, DF, Brasil \\ Corresponding author: A.R. Caetano \\ E-mail: alexandre.caetano@embrapa.br
}

Genet. Mol. Res. 12 (4): 6299-6308 (2013)

Received February 28, 2013

Accepted August 21, 2013

Published December 4, 2013

DOI http://dx.doi.org/10.4238/2013.December.4.17

\begin{abstract}
Arapaima gigas (Osteoglossidae) is one of the largest fish species in the Amazon Basin, attaining lengths of over $2.5 \mathrm{~m}$ and weights of over $100 \mathrm{~kg}$. Its flesh is prized, and it has great potential for production in aquaculture systems. However, live pirarucu cannot be reliably sexed visually, even after sexual development, since this species does not have clear external sexual dimorphism. Simple and inexpensive methods for sexing immature pirarucu based on DNA markers would facilitate production of this species in commercial operations. We analyzed $A$. gigas male and female DNA pools with 566 RAPD primers, generating 2609 fragments, with an estimated 1341 segregating polymorphic markers, and an estimated average spacing of $714 \mathrm{~kb}$, which corresponds to less than $0.1 \%$ of the species' genome. Two putative sex-specific fragments were initially identified in bulked
\end{abstract}


samples; but they were not confirmed in a study of individual male and female samples. We suggest that A. gigas has developed a nonchromosomal system of sex determination or, alternatively, that the species has undergone a recent loss of the chromosome carrying the sex-determining locus.

Key words: Neotropical fishes; RAPD; Sex determination; Bulked segregant analysis

\section{INTRODUCTION}

Pirarucu (Arapaima gigas) is found in the Amazon and Araguaia-Tocantins River basins, in a region spanning nine South American countries (Brazil, French Guiana, Suriname, Guyana, Venezuela, Colombia, Ecuador, Peru, and Bolivia). The species is considered to be the largest known fresh water scaled fish, with adults reaching $3 \mathrm{~m}$ in length and $200 \mathrm{~kg}$ in live weight (Nelson, 1994).

The species has had a major historical role in the diet of Native Americans inhabiting the Amazon region, as evidenced by stratified prehistoric deposits uncovered in archeological sites (Roosevelt et al., 1996). Starting in early 18th century, A. gigas has been heavily exploited by commercial fishing, mostly for production of salted and dried meat (Martinelli and Petrere Jr., 1999). Overfishing practices have led to the pirarucu becoming commercially extinct in areas around major Amazonian cities (Bayley and Petrere Jr., 1989). Commercial fishing was banned by the Brazilian government in early 2001, but it is currently permitted under strict guidance of environmental agencies, defining minimum size limits and excluding spawning seasons (Hrbek et al., 2007).

Pirarucu meat is devoid of bones, low in fat and highly valued in local and emerging domestic and international markets. Most of the supply is still derived from wild-caught fish, but the species presents several features that are highly desirable for commercial aquaculture production, such as rapid juvenile growth (yearlings can reach up to $10 \mathrm{~kg}$ of live weight) and high carcass yields. However, one of the major hurdles in developing pirarucu culture systems is the production of fry in controlled conditions, since captive breeding is still accomplished by randomly pairing adult males and females in earthen ponds so that they can spontaneously choose a mate, delimit a territory, build a nest, and breed (Chu-Koo et al., 2009).

Neither prepubescent nor adult pirarucu exhibit unambiguous sexual dimorphism. Sexing live adults can only be reliably accomplished around the reproductive phase of development, using ultrasonography, surgical methods (Carreiro et al., 2001), or quantitative metabolite assays (Chu-Koo et al., 2009). Therefore, simple and inexpensive methods for sexing immature pirarucu are needed to help enhance the production of this species in commercial operations.

The identification of sex-specific molecular markers for development of diagnostic assays for sexing prepubescent fish has been accomplished in a number of species: rainbow trout, Oncorhynchus mykiss (Iturra et al., 1997); tilapia, Oreochromis niloticus (Lee and Donaldson, 2001); African catfish, Clarias gariepinus (Kovács et al., 2000); yellow catfish, Pelteobagrus fulvidraco (Wang et al., 2009); and turbot, Psetta maxima (Casas et al., 2011). A sex-specific molecular marker for A. gigas is needed to assist the development and application of innovative 
methods for rearing this species on a commercial scale. In this study, we attempted to identify sex-specific molecular markers for pirarucu using bulked segregant analysis (Michelmore et al., 1991), a well-known strategy that has been successfully applied in several instances with similar objectives (Iturra et al., 1997; Kovács et al., 2000; Lee and Donaldson, 2001).

\section{MATERIAL AND METHODS}

\section{Sample collection and DNA extraction}

Samples were collected from the river system around Santarém $\left(2^{\circ} 26^{\prime} \mathrm{S} ; 54^{\circ} 42^{\prime} \mathrm{W}\right)$, Pará State, Brazil, from three discrete localities (Santa Maria do Tapará, Ipixuna, and Mucurituba), following the proper governmental authorizations (IBAMA license No. 16623-1, authentication code 37735557). Adult fish were caught, slaughtered, eviscerated, and sexed on the basis of the morphology of the sexual organs. Blood samples from captured animals were collected in EDTA tubes and DNA extractions were performed with a Genomic DNA Isolation Kit (RBC BioAmerica, Miami, FL, USA), according to the manufacturer protocol.

\section{Bulked segregant analysis with random amplified polymorphic DNA (RAPD) primers}

DNA samples from 11 females and 12 males were combined in equimolar amounts to form sex-specific bulks, according to procedures previously described (Michelmore et al., 1991). These two bulks were analyzed with a total of 566 RAPD primers (Table 1). PCRs were performed in duplicate with the following reagents: $2 \mu \mathrm{M}$ primer, $2.5 \mathrm{mM}$ dNTP (each), $25 \mathrm{mM} \mathrm{MgCl}_{2}, 0.5 \mathrm{U} \mathrm{Taq}_{\text {polymerase (Promega }}{ }^{\circ}$ ), 1X PCR buffer, 3 ng Bulk DNA, in a final volume of $10 \mu \mathrm{L}$. The thermal cycling parameters used were: 3 min at $94^{\circ} \mathrm{C} ; 40$ cycles of 15 $\mathrm{s}$ at $95^{\circ} \mathrm{C}, 30 \mathrm{~s}$ at $35^{\circ} \mathrm{C}$ and $1 \mathrm{~min}$ at $72^{\circ} \mathrm{C}$; with a final step of $7 \mathrm{~min}$ at $72^{\circ} \mathrm{C}$. PCR products were separated by electrophoresis on $1.5 \%$ agarose gels at $140 \mathrm{~V}$ for $3 \mathrm{~h}$ in $1 \mathrm{X}$ TBE buffer. Gels were stained with ethidium bromide, then visualized with a UV transilluminator and photographed with an EagleEye II imaging system (Stratagene). Primers that amplified sexspecific fragments were used to amplify each individual sample included in the initial male and female bulks.

\section{Estimates of the mean number of polymorphic RAPD markers segregating in the samples tested}

Twenty-two randomly selected RAPD primers (Operon ${ }^{\circledR}$ OPAB17; OPB08; OPN04, $09,11-13,15,16$; OPO07, 08, 10-16, 18-20; OPP08) were used to estimate the mean number of RAPD polymorphic markers segregating in the A. gigas samples used in the experiments. DNA samples from each of 12 males and 11 females were amplified separately, and RAPD fragments were separated on agarose gels as previously described. The total number of fragments and the total number of polymorphic fragments generated were determined. In addition, the total number of fragments generated with the 566 primers tested in the sex-specific bulks was also determined. 
Table 1. List of the RAPD primers (Operon ${ }^{\circledR}$ ) used to analyze Arapaima gigas male and female bulked DNA.

\begin{tabular}{|c|c|c|c|c|c|c|c|c|c|c|c|c|c|c|c|c|c|c|c|c|}
\hline \multirow[t]{2}{*}{ Kit } & \multicolumn{20}{|c|}{ Primer* } \\
\hline & 1 & 2 & 3 & 4 & 5 & 6 & 7 & 8 & 9 & 10 & 11 & 12 & 13 & 14 & 15 & 16 & 17 & 18 & 19 & 20 \\
\hline OPA & $\mathrm{x}$ & $\mathrm{x}$ & $\mathrm{x}$ & $\mathrm{x}$ & $\mathrm{x}$ & $\mathrm{x}$ & $\mathrm{x}$ & $\mathrm{x}$ & $\mathrm{x}$ & $\mathrm{x}$ & $\mathrm{x}$ & $\mathrm{x}$ & $\mathrm{x}$ & $\mathrm{x}$ & $\mathrm{x}$ & $\mathrm{x}$ & $\mathrm{x}$ & $\mathrm{x}$ & $\mathrm{x}$ & $\mathrm{x}$ \\
\hline OPAA & $\mathrm{x}$ & $\mathrm{x}$ & $\mathrm{x}$ & $\mathrm{x}$ & $\mathrm{x}$ & $\mathrm{x}$ & $\mathrm{x}$ & $\mathrm{x}$ & $\mathrm{x}$ & $\mathrm{x}$ & $\mathrm{x}$ & $\mathrm{x}$ & $\mathrm{x}$ & $\mathrm{x}$ & $\mathrm{x}$ & $\mathrm{x}$ & $\mathrm{x}$ & $\mathrm{x}$ & $\mathrm{x}$ & $\mathrm{x}$ \\
\hline OPAB & $\mathrm{x}$ & $\mathrm{x}$ & $\mathrm{x}$ & $\mathrm{x}$ & $\mathrm{x}$ & $\mathrm{x}$ & $\mathrm{x}$ & $\mathrm{x}$ & $\mathrm{x}$ & $\mathrm{x}$ & $\mathrm{x}$ & $\mathrm{x}$ & $\mathrm{x}$ & $\mathrm{x}$ & $\mathrm{x}$ & $\mathrm{x}$ & $\mathrm{x}$ & $\mathrm{x}$ & $\mathrm{x}$ & $\mathrm{x}$ \\
\hline OPAD & $\mathrm{x}$ & $\mathrm{x}$ & $\mathrm{x}$ & $\mathrm{x}$ & $\mathrm{x}$ & $\mathrm{x}$ & $\mathrm{x}$ & $\mathrm{x}$ & $\mathrm{x}$ & $\mathrm{x}$ & $\mathrm{x}$ & $\mathrm{x}$ & $\mathrm{x}$ & $\mathrm{x}$ & $\mathrm{x}$ & & $\mathrm{x}$ & & & \\
\hline OPAE & $\mathrm{x}$ & $\mathrm{x}$ & $\mathrm{x}$ & $\mathrm{x}$ & $\mathrm{x}$ & $\mathrm{x}$ & $\mathrm{x}$ & $\mathrm{x}$ & $\mathrm{x}$ & $\mathrm{x}$ & $\mathrm{x}$ & $\mathrm{x}$ & $\mathrm{x}$ & $\mathrm{x}$ & $\mathrm{x}$ & $\mathrm{x}$ & $\mathrm{x}$ & $\mathrm{x}$ & $\mathrm{x}$ & $\mathrm{x}$ \\
\hline OPAF & $\mathrm{x}$ & $\mathrm{x}$ & $\mathrm{x}$ & $\mathrm{x}$ & $\mathrm{x}$ & $\mathrm{x}$ & $\mathrm{x}$ & $\mathrm{x}$ & $\mathrm{x}$ & $\mathrm{x}$ & $\mathrm{x}$ & $\mathrm{x}$ & $\mathrm{x}$ & $\mathrm{x}$ & $\mathrm{x}$ & $\mathrm{x}$ & $\mathrm{x}$ & $\mathrm{x}$ & $\mathrm{x}$ & $\mathrm{x}$ \\
\hline OPAG & $\mathrm{x}$ & $\mathrm{x}$ & $\mathrm{x}$ & $\mathrm{x}$ & $\mathrm{x}$ & $\mathrm{x}$ & $\mathrm{x}$ & $\mathrm{x}$ & $\mathrm{x}$ & $\mathrm{x}$ & & $\mathrm{x}$ & $\mathrm{x}$ & $\mathrm{x}$ & $\mathrm{x}$ & $\mathrm{x}$ & $\mathrm{x}$ & $\mathrm{x}$ & $\mathrm{x}$ & $\mathrm{x}$ \\
\hline OPAI & & $\mathrm{x}$ & & $\mathrm{x}$ & & $\mathrm{x}$ & & & $\mathrm{x}$ & $\mathrm{x}$ & & $\mathrm{x}$ & $\mathrm{x}$ & $\mathrm{x}$ & $\mathrm{x}$ & $\mathrm{x}$ & $\mathrm{x}$ & $\mathrm{x}$ & $\mathrm{x}$ & $\mathrm{x}$ \\
\hline OPAX & $\mathrm{x}$ & $\mathrm{x}$ & $\mathrm{x}$ & $\mathrm{x}$ & $\mathrm{x}$ & $\mathrm{x}$ & $\mathrm{x}$ & $\mathrm{x}$ & $\mathrm{x}$ & $\mathrm{x}$ & $\mathrm{x}$ & $\mathrm{x}$ & $\mathrm{x}$ & $\mathrm{x}$ & $\mathrm{x}$ & $\mathrm{x}$ & $\mathrm{x}$ & $\mathrm{x}$ & $\mathrm{x}$ & $\mathrm{x}$ \\
\hline OPB & $\mathrm{x}$ & $\mathrm{x}$ & $\mathrm{x}$ & $\mathrm{x}$ & $\mathrm{x}$ & $\mathrm{x}$ & $\mathrm{x}$ & $\mathrm{x}$ & $\mathrm{x}$ & $\mathrm{x}$ & $\mathrm{x}$ & $\mathrm{x}$ & $\mathrm{x}$ & $\mathrm{x}$ & $\mathrm{x}$ & $\mathrm{x}$ & $\mathrm{x}$ & $\mathrm{x}$ & $\mathrm{x}$ & $\mathrm{x}$ \\
\hline OPBA & $\mathrm{x}$ & $\mathrm{x}$ & $\mathrm{x}$ & $\mathrm{x}$ & $\mathrm{x}$ & $\mathrm{x}$ & $\mathrm{x}$ & $\mathrm{x}$ & $\mathrm{x}$ & $\mathrm{x}$ & $\mathrm{x}$ & $\mathrm{x}$ & $\mathrm{x}$ & $\mathrm{x}$ & $\mathrm{x}$ & $\mathrm{x}$ & $\mathrm{x}$ & $\mathrm{x}$ & $\mathrm{x}$ & $\mathrm{x}$ \\
\hline OPC & $\mathrm{x}$ & $\mathrm{x}$ & $\mathrm{x}$ & $\mathrm{x}$ & $\mathrm{x}$ & $\mathrm{x}$ & & $\mathrm{x}$ & $\mathrm{x}$ & $\mathrm{x}$ & $\mathrm{x}$ & $\mathrm{x}$ & $\mathrm{x}$ & $\mathrm{x}$ & $\mathrm{x}$ & $\mathrm{x}$ & $\mathrm{x}$ & $\mathrm{x}$ & & $\mathrm{x}$ \\
\hline OPD & $\mathrm{x}$ & $\mathrm{x}$ & $\mathrm{x}$ & $\mathrm{x}$ & $\mathrm{x}$ & $\mathrm{x}$ & $\mathrm{x}$ & & $\mathrm{x}$ & $\mathrm{x}$ & $\mathrm{x}$ & $\mathrm{x}$ & $\mathrm{x}$ & $\mathrm{x}$ & $\mathrm{x}$ & $\mathrm{x}$ & $\mathrm{x}$ & $\mathrm{x}$ & $\mathrm{x}$ & $\mathrm{x}$ \\
\hline OPE & $\mathrm{x}$ & $\mathrm{x}$ & $\mathrm{x}$ & $\mathrm{x}$ & $\mathrm{x}$ & $\mathrm{x}$ & $\mathrm{x}$ & $\mathrm{x}$ & $\mathrm{x}$ & $\mathrm{x}$ & $\mathrm{x}$ & $\mathrm{x}$ & $\mathrm{x}$ & $\mathrm{x}$ & $\mathrm{x}$ & $\mathrm{x}$ & $\mathrm{x}$ & $\mathrm{x}$ & $\mathrm{x}$ & $\mathrm{x}$ \\
\hline OPF & $\mathrm{x}$ & $\mathrm{x}$ & $\mathrm{x}$ & $\mathrm{x}$ & $\mathrm{x}$ & $\mathrm{x}$ & $\mathrm{x}$ & $\mathrm{x}$ & $\mathrm{x}$ & $\mathrm{x}$ & $\mathrm{x}$ & $\mathrm{x}$ & $\mathrm{x}$ & & $\mathrm{x}$ & $\mathrm{x}$ & $\mathrm{x}$ & $\mathrm{x}$ & $\mathrm{x}$ & $\mathrm{x}$ \\
\hline OPG & $\mathrm{x}$ & $\mathrm{x}$ & $\mathrm{x}$ & $\mathrm{x}$ & $\mathrm{x}$ & $\mathrm{x}$ & $\mathrm{x}$ & $\mathrm{x}$ & $\mathrm{x}$ & $\mathrm{x}$ & $\mathrm{x}$ & $\mathrm{x}$ & & $\mathrm{x}$ & $\mathrm{x}$ & $\mathrm{x}$ & $\mathrm{x}$ & $\mathrm{x}$ & $\mathrm{x}$ & $\mathrm{x}$ \\
\hline $\mathrm{OPH}$ & & & & & & & & & & & & $\mathrm{x}$ & & & & $\mathrm{x}$ & & $\mathrm{x}$ & & \\
\hline OPI & $\mathrm{x}$ & $\mathrm{x}$ & $\mathrm{x}$ & $\mathrm{x}$ & $x$ & $\mathrm{x}$ & $\mathrm{x}$ & $\mathrm{x}$ & $\mathrm{x}$ & $\mathrm{x}$ & $\mathrm{x}$ & $\mathrm{x}$ & & $\mathrm{x}$ & $\mathrm{x}$ & $\mathrm{x}$ & $\mathrm{x}$ & $\mathrm{x}$ & $\mathrm{x}$ & $x$ \\
\hline OPJ & $\mathrm{x}$ & $\mathrm{x}$ & $\mathrm{x}$ & $\mathrm{x}$ & $\mathrm{x}$ & $\mathrm{x}$ & $\mathrm{x}$ & $\mathrm{x}$ & $\mathrm{x}$ & $\mathrm{x}$ & $\mathrm{x}$ & $\mathrm{x}$ & $\mathrm{x}$ & $\mathrm{x}$ & $\mathrm{x}$ & $\mathrm{x}$ & $\mathrm{x}$ & $\mathrm{x}$ & $\mathrm{x}$ & $\mathrm{x}$ \\
\hline OPK & $\mathrm{x}$ & $\mathrm{x}$ & $\mathrm{x}$ & $\mathrm{x}$ & $\mathrm{x}$ & $\mathrm{x}$ & $\mathrm{x}$ & $\mathrm{x}$ & $\mathrm{x}$ & $\mathrm{x}$ & $\mathrm{x}$ & $\mathrm{x}$ & $\mathrm{x}$ & $\mathrm{x}$ & $\mathrm{x}$ & $\mathrm{x}$ & $\mathrm{x}$ & $\mathrm{x}$ & $\mathrm{x}$ & $\mathrm{x}$ \\
\hline OPL & $\mathrm{x}$ & $\mathrm{x}$ & $\mathrm{x}$ & $\mathrm{x}$ & $\mathrm{x}$ & $\mathrm{x}$ & $\mathrm{x}$ & $\mathrm{x}$ & $\mathrm{x}$ & $\mathrm{x}$ & $\mathrm{x}$ & $\mathrm{x}$ & $\mathrm{x}$ & $\mathrm{x}$ & $\mathrm{x}$ & $\mathrm{x}$ & $\mathrm{x}$ & $\mathrm{x}$ & $\mathrm{x}$ & $\mathrm{x}$ \\
\hline OPM & $\mathrm{x}$ & $\mathrm{x}$ & $\mathrm{x}$ & & $\mathrm{x}$ & $\mathrm{x}$ & $\mathrm{x}$ & $\mathrm{x}$ & $\mathrm{x}$ & $\mathrm{x}$ & $\mathrm{x}$ & $\mathrm{x}$ & $\mathrm{x}$ & $\mathrm{x}$ & $\mathrm{x}$ & $\mathrm{x}$ & $\mathrm{x}$ & $\mathrm{x}$ & $\mathrm{x}$ & $\mathrm{x}$ \\
\hline OPN & $\mathrm{x}$ & $\mathrm{x}$ & $\mathrm{x}$ & $\mathrm{x}$ & $\mathrm{x}$ & $\mathrm{x}$ & $\mathrm{x}$ & $\mathrm{x}$ & $\mathrm{x}$ & $\mathrm{x}$ & $\mathrm{x}$ & $\mathrm{x}$ & $\mathrm{x}$ & $\mathrm{x}$ & $\mathrm{x}$ & $\mathrm{x}$ & $\mathrm{x}$ & $\mathrm{x}$ & $\mathrm{x}$ & $\mathrm{x}$ \\
\hline OPO & $\mathrm{x}$ & $\mathrm{x}$ & $\mathrm{x}$ & $\mathrm{x}$ & $\mathrm{x}$ & $\mathrm{x}$ & $\mathrm{x}$ & $\mathrm{x}$ & $\mathrm{x}$ & $\mathrm{x}$ & $\mathrm{x}$ & $\mathrm{x}$ & $\mathrm{x}$ & $\mathrm{x}$ & $\mathrm{x}$ & $\mathrm{x}$ & $\mathrm{x}$ & $\mathrm{x}$ & $\mathrm{x}$ & $\mathrm{x}$ \\
\hline OPP & $\mathrm{x}$ & $\mathrm{x}$ & $\mathrm{x}$ & $\mathrm{x}$ & $\mathrm{x}$ & $\mathrm{x}$ & $\mathrm{x}$ & $\mathrm{x}$ & $\mathrm{x}$ & $\mathrm{x}$ & $\mathrm{x}$ & $\mathrm{x}$ & $\mathrm{x}$ & $\mathrm{x}$ & $\mathrm{x}$ & $\mathrm{x}$ & $\mathrm{x}$ & $\mathrm{x}$ & $\mathrm{x}$ & $\mathrm{x}$ \\
\hline OPR & $\mathrm{x}$ & $\mathrm{x}$ & & $\mathrm{x}$ & & $\mathrm{x}$ & $\mathrm{x}$ & $\mathrm{x}$ & & $\mathrm{x}$ & & $\mathrm{x}$ & $\mathrm{x}$ & $\mathrm{x}$ & & $\mathrm{x}$ & $\mathrm{x}$ & $\mathrm{x}$ & $\mathrm{x}$ & $\mathrm{x}$ \\
\hline OPS & $\mathrm{x}$ & $\mathrm{x}$ & $\mathrm{x}$ & $\mathrm{x}$ & $\mathrm{x}$ & $\mathrm{x}$ & $\mathrm{x}$ & $\mathrm{x}$ & $\mathrm{x}$ & $\mathrm{x}$ & $\mathrm{x}$ & $\mathrm{x}$ & $\mathrm{x}$ & $\mathrm{x}$ & $\mathrm{x}$ & $\mathrm{x}$ & $\mathrm{x}$ & $\mathrm{x}$ & $\mathrm{x}$ & $\mathrm{x}$ \\
\hline OPT & $\mathrm{x}$ & & $\mathrm{x}$ & $\mathrm{x}$ & $\mathrm{x}$ & $\mathrm{x}$ & $\mathrm{x}$ & & $\mathrm{x}$ & $\mathrm{x}$ & & $\mathrm{x}$ & $\mathrm{x}$ & & $\mathrm{x}$ & $\mathrm{x}$ & $\mathrm{x}$ & $\mathrm{x}$ & $\mathrm{x}$ & $\mathrm{x}$ \\
\hline OPU & $\mathrm{x}$ & & $\mathrm{x}$ & & & $\mathrm{x}$ & & & & $\mathrm{x}$ & & & & & $\mathrm{x}$ & $\mathrm{x}$ & & & $\mathrm{x}$ & $\mathrm{x}$ \\
\hline OPV & $\mathrm{x}$ & $\mathrm{x}$ & $\mathrm{x}$ & $\mathrm{x}$ & $\mathrm{x}$ & $\mathrm{x}$ & $\mathrm{x}$ & $\mathrm{x}$ & $\mathrm{x}$ & $\mathrm{x}$ & $\mathrm{x}$ & $\mathrm{x}$ & & $\mathrm{x}$ & $\mathrm{x}$ & $\mathrm{x}$ & $\mathrm{x}$ & $\mathrm{x}$ & $\mathrm{x}$ & $\mathrm{x}$ \\
\hline OPW & $\mathrm{x}$ & $\mathrm{x}$ & $\mathrm{x}$ & $\mathrm{x}$ & $\mathrm{x}$ & $\mathrm{x}$ & $\mathrm{x}$ & $\mathrm{x}$ & $\mathrm{x}$ & & $\mathrm{x}$ & $\mathrm{x}$ & $x$ & $\mathrm{x}$ & $\mathrm{x}$ & $\mathrm{x}$ & $\mathrm{x}$ & $\mathrm{x}$ & $\mathrm{x}$ & $\mathrm{x}$ \\
\hline OPX & $\mathrm{x}$ & & $\mathrm{x}$ & $\mathrm{x}$ & $\mathrm{x}$ & $\mathrm{x}$ & $\mathrm{x}$ & $\mathrm{x}$ & $\mathrm{x}$ & $\mathrm{x}$ & $\mathrm{x}$ & $\mathrm{x}$ & $\mathrm{x}$ & $\mathrm{x}$ & $\mathrm{x}$ & $\mathrm{x}$ & $\mathrm{x}$ & $\mathrm{x}$ & $\mathrm{x}$ & $\mathrm{x}$ \\
\hline OPY & & $\mathrm{x}$ & $\mathrm{x}$ & $\mathrm{x}$ & $\mathrm{x}$ & $\mathrm{x}$ & $\mathrm{x}$ & $\mathrm{x}$ & $\mathrm{x}$ & $\mathrm{x}$ & $\mathrm{x}$ & $\mathrm{x}$ & $\mathrm{x}$ & $\mathrm{x}$ & $\mathrm{x}$ & $\mathrm{x}$ & $\mathrm{x}$ & $\mathrm{x}$ & $\mathrm{x}$ & $\mathrm{x}$ \\
\hline OPZ & $\mathrm{x}$ & $\mathrm{x}$ & $\mathrm{x}$ & $\mathrm{x}$ & $\mathrm{x}$ & $\mathrm{x}$ & $\mathrm{x}$ & $\mathrm{x}$ & $\mathrm{x}$ & $\mathrm{x}$ & $\mathrm{x}$ & $\mathrm{x}$ & $\mathrm{x}$ & $\mathrm{x}$ & $\mathrm{x}$ & $\mathrm{x}$ & $\mathrm{x}$ & $\mathrm{x}$ & $\mathrm{x}$ & $\mathrm{x}$ \\
\hline
\end{tabular}

*Primer sequences available at [http://www.google.com/url?sa=t\&rct=j\&q=operon\%20rapd\%20primer\%20seque nce\&source $=$ web $\& c d=2 \&$ ved $=0 \mathrm{CFwQFjAB} \& u r l=\mathrm{http} \% 3 \mathrm{~A} \% 2 \mathrm{~F} \% 2 \mathrm{Fwww}$.operon.com $\% 2 \mathrm{Fproducts} \% 2 \mathrm{Fdownloa}$ ds\%2FOperonsRAPD10merSequences.xls\&ei=2Ga0T7aSCoHk9ATWhe36Dw\&usg=AFQjCNEmmxkQoQR54d 8YbT872IRlsqkpJw].

These results were used to estimate the average number (n) of polymorphic RAPD markers segregating in the tested samples using the formula:

$$
\mathrm{n}=\mathrm{x}(\mathrm{y} / \mathrm{z})
$$

where $x$ is the total number of RAPD fragments amplified in the bulked segregant analysis and $y / z$ represents the estimated average proportion of RAPD polymorphic fragments amplified in the samples included in the study, obtained by dividing (y) the number of observed polymorphic fragments by $(\mathrm{z})$ the total number of RAPD fragments obtained.

\section{RESULTS}

\section{Bulked segregant analysis}

A total of 2609 RAPD fragments were amplified with the 566 primers tested (an aver- 
age of 4.6 fragments per primer, Figure 1). Seventy percent of the primers amplified at least one RAPD fragment and 70 primers did not generate any fragments. Two primers amplified putative sex-specific fragments in the bulk evaluation phase. A male-specific fragment of approximately $700 \mathrm{bp}$ was amplified with primer OPAB17 (Figure 2A), and a female-specific fragment of approximately $1500 \mathrm{bp}$ was amplified with primer OPP08 (Figure 2B). The amplification of individual male and female samples with primers OPAB17 (Figure 3) and OPP08 (data not shown) revealed that the previously observed putative sex-specific fragments could actually be amplified from both males and females.

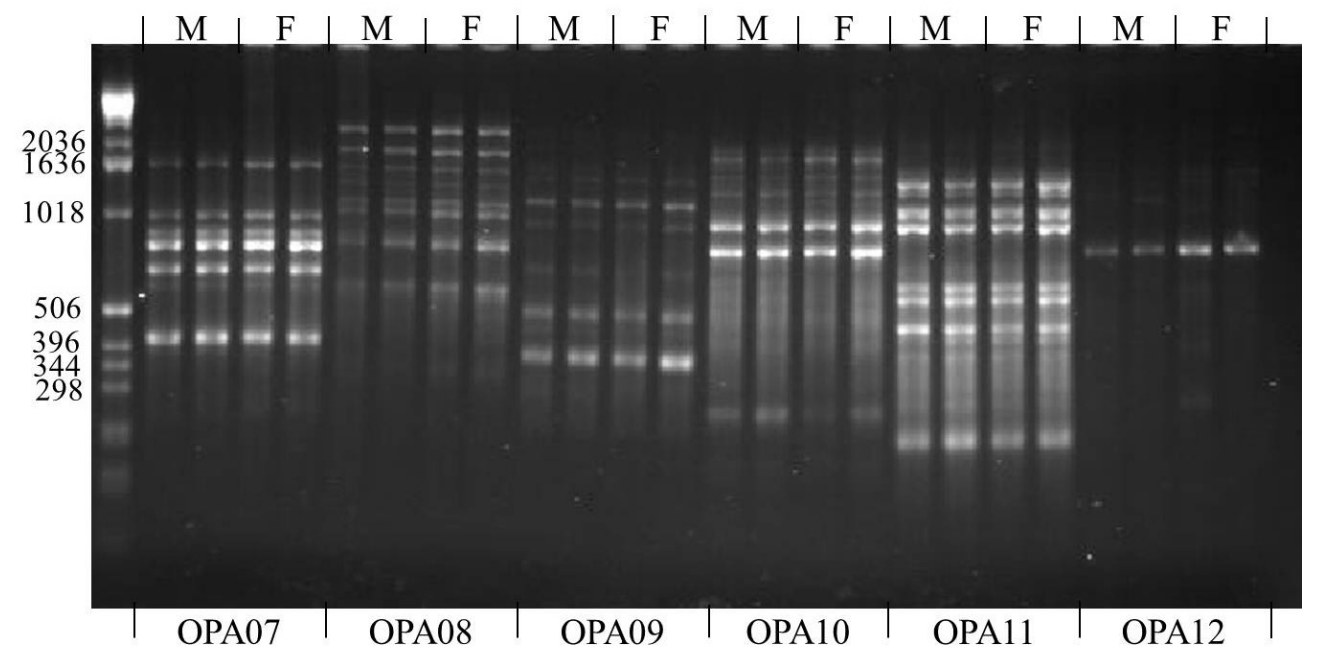

Figure 1. Example of RAPD fragments amplified with different primers from Arapaima gigas male (M) and female $(\mathrm{F})$ bulked DNA.
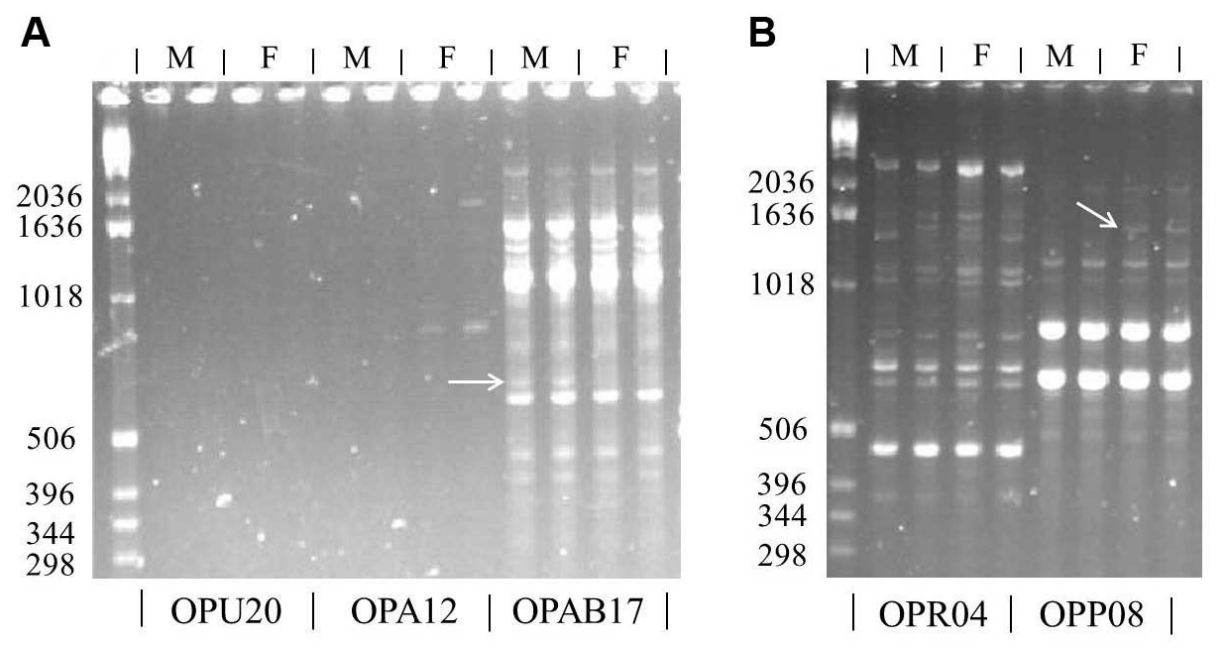

Figure 2. Putative Arapaima gigas sex-specific fragments (arrows) amplified from A. male (M) and B. female (F) bulked DNA with primers OPAB17 and OPP08, respectively. 


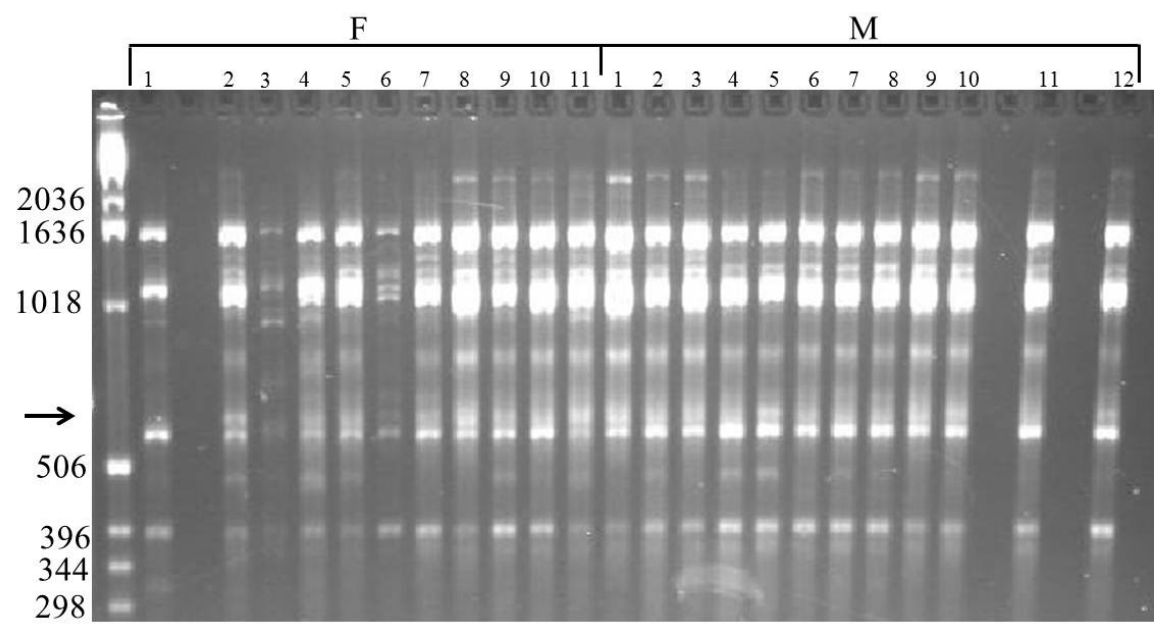

Figure 3. RAPD fragments amplified from Arapaima gigas individual male (M) and female (F) samples with primer OPAB17, showing the putative male-specific fragment (arrow) can be observed in samples from both sexes.

\section{Level of RAPD polymorphism in the tested samples and average marker spacing}

The 22 primers used for evaluating the level of polymorphism observed in the sampled individuals generated a total of 214 RAPD fragments (z). Of these, 110 fragments (y) were found to be polymorphic in the 23 individuals included in the bulked segregant analysis (Figure 4). The estimated average proportion of polymorphic RAPD fragments amplified in the samples included in the study $(\mathrm{y} / \mathrm{z})$ was $51.4 \%$. Considering that a total of 2609 RAPD fragments were amplified in the bulked segregant analysis, we estimate that a total of 1341 polymorphic fragments were segregating in the samples analyzed.

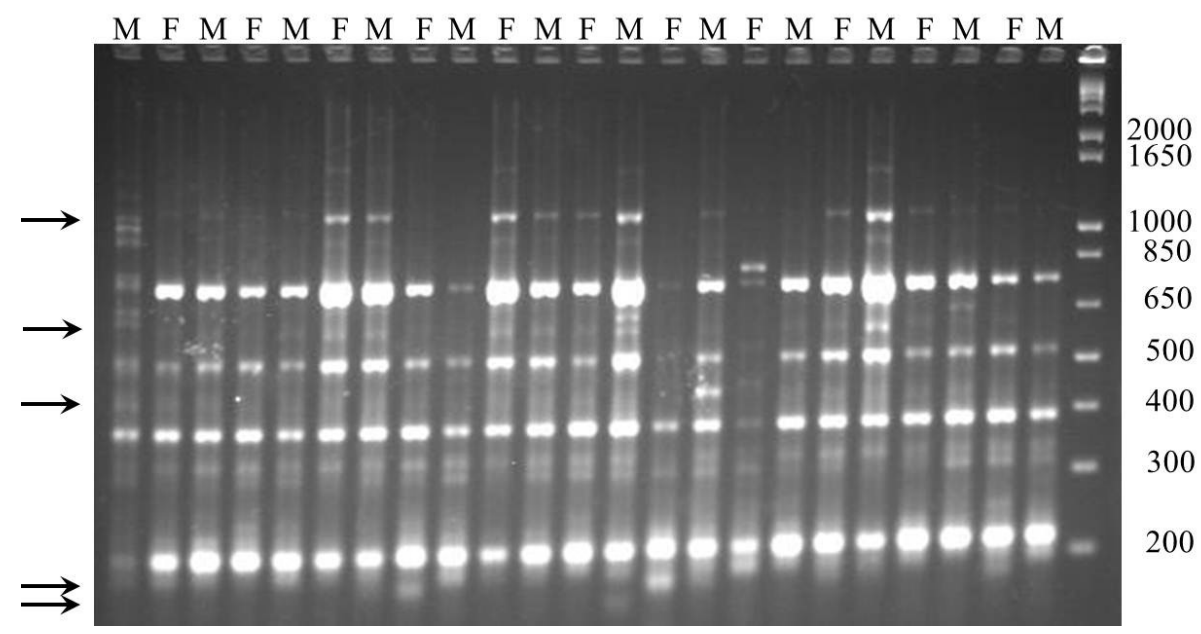

Figure 4. RAPD fragments amplified from Arapaima gigas individual male (M) and female (F) samples with primer OPN16. Arrows indicate polymorphic fragments. 
Considering that the haploid nuclear content of A. gigas has been estimated as 0.98 pg (Hinegardner and Rosen, 1972), we estimate that the pirarucu genome has a total length of $958.44 \mathrm{Mbp}\left[\left(0.978 \times 10^{3} \mathrm{Mbp} / \mathrm{pg}\right) \times 0.98 \mathrm{pg}\right]$, using the formula proposed by Dolezel et al. (2003). Thus, we can infer that the bulked segregant analysis resulted in the mapping of polymorphic RAPD fragments with an average spacing of $714 \mathrm{kbp}$, assuming that the fragments were randomly distributed throughout the species' genome.

\section{DISCUSSION}

The development of simple and efficient methods for sexing prepubescent fish is an essential step for appropriate broodstock management of species that do not exhibit well-defined sexual dimorphism. The inability to identify the sex of juveniles prevents early assortment of appropriate proportions of males and females for establishing optimal selection and matting strategies. This issue is particularly critical for larger species, because fewer individuals tend to be kept as broodstock for reasons of production efficiency. High levels of behavior-induced stress caused by inadequate management of breeding animals, due to the allocation of disproportionate numbers of females to males in breeding tanks, can jeopardize the production of fry (Carreiro et al., 2011). In species such as sturgeon (Huso huso), where sex-specific molecular markers have not been identified (Keyvanshokooh et al., 2007), surgical (Falahatkar et al., 2011) and non-invasive (Masoudifard et al., 2011) methods have been developed for sexing fish. This has enabled discrete management practices for males and females, which are raised for the production of meat and eggs (caviar), respectively (Falahatkar et al., 2011).

Different methods have been developed to generate monosex populations of several fish species, such as induced sex reversal of alevins by hormonal treatments, and induced gynogenesis through thermal or hyperbaric shocking of fertilized eggs (Pandian and Koteeswaran, 1998; Lee and Donaldson, 2001). In some cases, these methods have been widely adopted by producers as a consequence of the obtained gains in productivity and profitability (Beardmore et al., 2001). However, the effective use of these technologies is also highly dependent on diagnostic methods for the identification of "supermales" (YY) or "superfemales" (WW) for use as broodstock.

A number of different sex determination systems, ranging from genetic to environmental sex determination, have been reported for different species of fish. Genetic sex determination systems vary from exclusively chromosomal with heterogametic males (XY) or females (ZW), to systems influenced by autosomal genes, or of polygenic nature (Devlin and Nagahama, 2002). In addition, different sex determination systems have been found in species from the same genus, such as the tilapia Oreochromis sp, where classic male heterogametic (O. niloticus) and female heterogametic (O. aureus) species have been reported (Campos-Ramos et al., 2001). Even though genetic factors probably regulate sex determination in most fish species, only a small proportion of teleosts studied actually show distinct sex chromosomes that can be morphologically identified by standard cytogenetic analysis (Arkhipchuk, 1995). Nevertheless, heteromorphic sex chromosomes have been observed in more than 176 species of fish from different groups (Devlin and Nagahama, 2002); this includes species belonging to the family comprising A. gigas, such as Osteoglossum bicirrhosum (Uyeno and Miller, 1971). However, A. gigas has been shown to lack differentiated sex chromosomes (Marques et al., 2006) indicating that, if the species presents a chromosomal sex determination system, the 
differentiated genomic region associated with the sex determining locus (SDL) is not large enough to be morphologically identified through standard karyotype analysis.

The present study took into account all of the aforementioned issues and was designed to identify sex-specific RAPD fragments, if $A$. gigas has a classic male or female heterogametic sex determination system. Compared to other methods that have been used previously for identifying sequences present and absent from a genome, bulked segregant analysis with RAPD markers is a simple, low-cost approach, which has been used successfully in several recent studies aimed at identifying sex-specific markers in a number of species (Iturra et al., 1997; Lee and Donaldson, 2001; Gebler et al., 2007; Mariotti et al., 2009; Casas et al., 2011). Even in the current context where sequencing and resequencing of complete genomes are becoming widely accessible due to the greater capacity and reduced cost conferred by recent technological advances (Metzker, 2010), this methodology is still a proven approach with great potential to provide positive results in similar studies. Despite not identifying sex-specific markers for $A$. gigas, our estimates of genome coverage with segregating polymorphic markers revealed that, if this species actually has a chromosomal sex determination system, the SDL must be contained within a genomic region of minimal proportions, containing less than $714 \mathrm{~kb}$; this would be equivalent to less than $0.1 \%$ of the species' genome.

The degenerative processes of content reduction and loss of gene function in the heterogametic chromosome have been widely described and are consensually accepted as the result of the recombination suppression caused by the acquisition of the sex-determining gene by an autosome, followed by the accumulation of mutations (Rice, 1987; Charlesworth and Charlesworth, 2000; Steinemann and Steinemann, 2000; Lahn et al, 2001; Graves, 1995, 2006; Graves et al., 2006). A. gigas belongs to one of the oldest groups of teleosts, which originated in the Jurassic period (Lavoué and Sullivan, 2004). Therefore, if this species has a classical chromosomal male or female heterogametic sex determination system (XY or ZW), the sex chromosomes should have accumulated significant changes over the last 150 million years, as observed in other species (Marshall Graves and Shetty, 2001; Marshall Graves, 2008). Conversely, the duplication that led to the formation of the SDL in the medaka (Oryzias latipes) was calculated to have occurred $\sim 10$ million years ago (Kondo et al., 2004), and the region was shown to have accumulated only $258 \mathrm{kbp}$ over this period. This is equivalent to $\sim 0.03 \%$ of the species' genome, in what is considered to be the youngest vertebrate Y chromosome known with an identified sex-determining gene (Kondo et al., 2006).

The lack of large genomic differences associated with the A. gigas SDL could be a consequence of the species having developed a non-chromosomal system of sex determination, which could be influenced by polygenic and/or environmental factors. Alternatively, it is also possible that $A$. gigas has undergone a recent loss of the chromosome carrying the SDL, as reported by Marshall Graves and Shetty (2001) in two mammals of the genus Elliobus. These two species of rodent have completely lost the Y chromosome and have no SRY gene, the consensual mammalian SDL (Just et al., 1995). Marshall Graves and Shetty (2001) suggested that perhaps a new sex-determining gene has arisen in these species, leading to the redundancy of $S R Y$ and the Y chromosome itself, which completely degraded over time.

Analyses of the structure of synaptonemal complexes have been used to identify the sex-specific regions of fish meiotic chromosome pairings that could not be identified by traditional karyotype analysis (Carrasco et al., 1999; Campos-Ramos et al., 2001). This approach could be used to evaluate the A. gigas genome for the presence of heterogametic 
regions. Furthermore, experiments involving crosses between sex-reversed fish, generated by hormonal treatment or produced by artificial induction of gynogenesis, have been used extensively to elucidate the mechanism of sex determination of a large number of fish species (Lee and Donaldson, 2001; Xiang-Shan et al., 2010). Such experiments are also likely to help elucidate the mechanism of sex determination of A. gigas, and could lead to the development of a diagnostic method for sexing prepubescent fish, which would have a significant impact on the development of the commercial aquaculture of this species.

\section{ACKNOWLEDGMENTS}

The authors are grateful to Cláudia Fernanda Pantoja da Silva, Raimundo Nonato Guimaraes Teixeira, Edilvar Santos Pimentel, and Luiz Alberto Vasconcelos for assistance with sample collection, and the local fishing communities for providing captured animals for sexing and tissue collection. S.R. Paiva and A.R. Caetano are recipients of CNPq fellowships.

\section{REFERENCES}

Arkhipchuk VV (1995). Role of chromosomal and genome mutations in the evolution of bony fishes. Hydrobiol. J. 31: 55-65.

Bayley PB and Petrere Jr M (1989). Amazon Fisheries: Assessment Methods, Current Status and Management Options. In: Proceedings of the International Large River Symposium (Dodge DP, ed.). Canadian Special Publications. Fish. Aquat. Sci. 106: 385-398.

Beardmore JA, Mair GC and Lewis RI (2001). Monosex male production in finfish as exemplified by tilapia: applications, problems, and prospects. Aquaculture 197: 283-301.

Campos-Ramos R, Harvey SC, Masabanda JS, Carrasco LA, et al. (2001). Identification of putative sex chromosomes in the blue tilapia, Oreochromis aureus, through synaptonemal complex and FISH analysis. Genetica 111: 143-153.

Carrasco LAP, Penman DJ and Bromage N (1999). Evidence for the presence of sex chromosomes in the nile tilapia (Oreochronics niloticus) from synaptonemal complex analysis of XX, XY and YY genotypes. Aquaculture 173: 207-218.

Carreiro CRP, Furtado Neto MA, Mesquita PEC and Bezerra TA (2011). Sex determination in the giant fish of Amazon Basin Arapaima gigas (Osteoglossiformes, Arapaimatidae), using laparoscopy. Acta Amazonica 41: 415-420.

Casas L, Sanchez L and Orban L (2011). Sex-associated DNA markers from turbot. Mar. Biol. Res. 7: 378-387.

Charlesworth B and Charlesworth D (2000). The degeneration of Y chromosomes. Philos. Trans. R Soc. Lond. B Biol. Sci. 355: 1563-1572.

Chu-Koo F, Dugue R, Alvan AM, Casanova DA, et al. (2009). Gender determination in the Paiche or Pirarucu (Arapaima gigas) using plasma vitellogenin, 17beta-estradiol, and 11-ketotestosterone levels. Fish Physiol. Biochem. 35: 125-136.

Devlin RH and Nagahama Y (2002). Sex determination and sex differentiation in fish: an overview of genetics, physiological and environmental influences. Aquaculture 208: 191-364.

Dolezel J, Bartos J, Voglmayr H and Greilhuber J (2003). Nuclear DNA content and genome size of trout and human. Cytometry A 51: 127-128.

Falahatkar B, Gilani MHT, Falahatkar S and Abbasalizadeh A (2011). Laparoscopy, a minimally-invasive technique for sex identification in cultured great sturgeon Huso huso. Aquaculture 321: 273-279.

Gebler P, Wolko L and Knaflewski M (2007). Identification of molecular markers for selection of supermale (YY) asparagus plants. J. Appl. Genet. 48: 129-131.

Graves JA (1995). The origin and function of the mammalian Y chromosome and Y-borne genes - an evolving understanding. Bioessays 17: 311-320.

Graves JA (2006). Sex chromosome specialization and degeneration in mammals. Cell 124: 901-914.

Graves JAM, Koina E and Sankovic N (2006). How the gene content of the human sex chromosomes evolved. Curr. Opin. Genet. Dev. 16: 1-6.

Hinegardner R and Rosen DE (1972). Cellular DNA content and the evolution of teleostean fishes. Am. Nat. 106: 621-644.

Hrbek T, Crossa M and Farias IP (2007). Conservation strategies for Arapaima gigas (Schinz, 1822) and the Amazonian varzea ecosystem. Braz J. Biol. 67: 909-917. 
Iturra P, Medrano JF, Bagley M, Lam N, et al. (1997). Identification of sex chromosome molecular markers using RAPDs and fluorescent in situ hybridization in rainbow trout. Genetica 101: 209-213.

Just W, Rau W, Vogel W, Akhverdian M, et al. (1995). Absence of Sry in species of the vole Ellobius. Nat. Genet. 11: 117-118.

Keyvanshokooh S, Pourkazemi M and Kalbassi MR (2007). The RAPD technique failed to identify sex-specific sequences in beluga (Huso huso). J. Appl. Ichthyol. 23: 1-2.

Kondo M, Nanda I, Hornung U, Schmid M, et al. (2004). Evolutionary origin of the medaka Y chromosome. Curr. Biol. 14: 1664-1669.

Kondo M, Hornung U, Nanda I, Imai S, et al. (2006). Genomic organization of the sex-determining and adjacent regions of the sex chromosomes of medaka. Genome Res. 16: 815-826.

Kovács B, Egedi S, Bartfai R and Orban L (2000). Male-specific DNA markers from African catfish (Clarias gariepinus). Genetica 110: 267-276.

Lahn BT, Pearson NM and Jegalian K (2001). The human Y chromosome, in the light of evolution. Nat. Rev. Genet. 2: 207-216.

Lavoué S and Sullivan JP (2004). Simultaneous analysis of five molecular markers provides a well-supported phylogenetic hypothesis for the living bony-tongue fishes (Osteoglossomorpha: Teleostei). Mol. Phylogenet. Evol. 33: 171-185.

Lee CS and Donaldson EM (2001). General discussion on reproductive biotechnology in fish aquaculture. Aquaculture 193: 303-320.

Mariotti B, Manzano S, Kejnovsky E, Vyskot B, et al. (2009). Accumulation of Y-specific satellite DNAs during the evolution of Rumex acetosa sex chromosomes. Mol. Genet. Genomics 281: 249-259.

Marques DK, Venere PC and Galetti Jr PM (2006). Chromosomal characterization of the bonytongue Arapaima gigas (Osteoglossiformes: Arapaimidae). Neotrop. Ichthyol. 4: 215-218.

Marshall Graves JA (2008). Weird animal genomes and the evolution of vertebrate sex and sex chromosomes. Annu. Rev. Genet. 42: 565-586.

Marshall Graves JA and Shetty S (2001). Sex from W to Z: evolution of vertebrate sex chromosomes and sex determining genes. J. Exp. Zool. 290: 449-462.

Martinelli NMC and Petrere Jr M (1999). Morphometric relationships and indirect determination of the length frequency structure of the pirarucu, Arapaima gigas (Cuvier), in Brazilian Amazonia. Fish. Manage. Ecol. 6: 233-240.

Masoudifard M, Vajhi AR, Moghim M, Nazari RM, et al. (2011). High validity sex determination of three years old cultured beluga sturgeon (Huso huso) using ultrasonography. J. Appl. Ichthyol. 27: 643-647.

Metzker ML (2010). Sequencing technologies - the next generation. Nat. Rev. Genet. 11: 31-46.

Michelmore RW, Paran I and Kesseli RV (1991). Identification of markers linked to disease-resistance genes by bulked segregant analysis: a rapid method to detect markers in specific genomic regions by using segregating populations. Proc. Natl. Acad. Sci. U. S. A. 88: 9828-9832.

Nelson JS (1994). Fishes of the World. 3rd edn. John Wiley and Sons, Inc., New York.

Pandian TJ and Koteeswaran R (1998). Ploidy induction and sex control in fish. Hydrobiologia 384: 167-243.

Rice WR (1987). Genetic hitchhiking and the evolution of reduced genetic activity of the Y sex chromosome. Genetics 116: 161-167.

Roosevelt AC, Lima da Costa M, Lopes Machado C, Michab M, et al. (1996). Paleoindian cave dwellers in the Amazon: the peopling of the Americas. Science 272: 373-384.

Steinemann M and Steinemann S (2000). Common mechanisms of Y chromosome evolution. Genetica 109: 105-111.

Uyeno T and Miller RR (1971). Multiple sex chromosomes in a Mexican cyprinodontid fish. Nature 231: 452-453.

Wang D, Mao HL, Chen HX, Liu HQ, et al. (2009). Isolation of Y- and X-linked SCAR markers in yellow catfish and application in the production of all-male populations. Anim. Genet. 40: 978-981.

Xiang-Shan J, Song-Lin C, Jing-Feng Y, Hong-Yu M, et al. (2010). Artificial gynogenesis and assessment of homozygosity in meiotic gynogens of spotted halibut (Verasper variegates). Aquac. Int. 18: 1151-1161. 